\title{
The Utilization Of Testimonials Menu As A Buyer Satisfaction Information Media On Raharja Internet Cafe E-Commerce Website
}

\author{
Henderi ${ }^{1}$, Harph Zcull ${ }^{2}$, Cheetah Savana Putri ${ }^{3}$ \\ ${ }^{1,3}$ Raharja University, Jl. Jendral Sudirman No.40 Modernland, Cikokol, Tangerang \\ ${ }^{2}$ Ramoz University \\ e-mail: henderi@raharja.info, harph@gmail.com,cheetah@raharja.info
}

To cite this document:

henderi, henderi, harrison, robert, \& Putri, C. (2019). Utilization of Testimonials Menu as Submission Media Information on Buyer Satisfaction on the Website E-Commerce Raharja Internet Café. Aptisi Transactions On Technopreneurship (ATT), 1(1), 104-111.

Retrieved from https://pandawan.aptisi.or.id/index.php/att/article/view/35

\begin{abstract}
Raharja Internet Cafe is a facility at Raharja College, which provides various needs for Raharja's private lecture activities. Raharja Internet Cafe is used to help lecture activities by facilitating students such as computers, printers and scanners. Also helps students to install or service iPad. However, sometimes the facilities available at Raharja Internet Cafe are still experiencing problems so students are less interested in visiting Raharja Internet Cafe. This study uses 2 (two) methods, namely the literature review method and questionnaire. As a result, to make it easier for sellers and buyers to know the quality of services provided by Raharja Internet Cafe to Pribadi Raharja, Raharja Internet Cafe's website is used by adding testimonials menus. In the testimonials menu, there are many testimonials that have been given by Raharja Internet Cafe users. And the results obtained from the research conducted are that Raharja Internet Cafe is very helpful in lecturing activities.
\end{abstract}

Keywords: Facilities, Services, Testimonials, Raharja Internet Cafe

\section{Introduction}

Facility is a place provided to meet public interests. In the teaching and learning process activities, ranging from elementary schools to universities, facilities are an important part [1]. It cannot be denied, that facilities are one of the supporting factors in determining the quality of education which is also the standard of the relevant educational institutions. This proves that facilities greatly affect an agency as supporting activities in educational activities [2].

As a higher education institution, in its implementation it must also be equipped with several facilities to support the success of the objectives of the college program [3]. The facility that is one of the supporters in the success of a college is by following Tridharma through organizing, providing and providing services to students [4].

Raharja College is one of the higher education institutions that is engaged in information technology, which continues to carry out development and improvement, both in the lecture system and in the service system at the Raharja College [5]. 


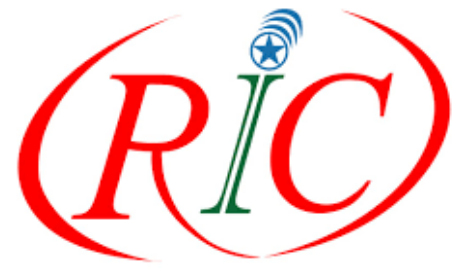

Gambar 1. Logo Raharja Internet Cafe

Raharja Internet Cafe (RIC) as a facility in Raharja College which is provided for College Students Raharja in assisting in providing the needs for lecture activities [6]. Prog requirement provided in the Internet Cafe is like installing the latest iOS iPad, upgrade iPad, iPad and Laptop Accessories, as well as provide service iPad and laptops, as well as several other needs. Raharja Internet Cafe provides comfortable rooms by facilitating students of Raharja College in scanning, printing and Student Information Systems (SIS). However, there are a number of obstacles, such as a non-functioning computer or a slow internet network, and the lack of facilities that make Raharja students gradually leave Raharja Internet Cafe [7].

The service quality of RIC officers is also one that affects Pribadi Raharja for visiting Raharja Internet Cafe. Parasuraman, Zeithaml, and Berry (1991) state that "service quality is a comparison between services that consumers expect from the service they receive" [8]. In this context, it can also be said that when services received by consumers are in accordance with their expectations, it can be said that the quality of the service is good and satisfying. Likewise with services or services that consumers receive exceed their expectations, it can be said that the quality of service they receive is of an ideal quality [9]. However, if the service received is lower than expected, then the quality of service will be said to be bad. Quality of service begins with the needs of users that end with user responses. A comprehensive assessment of a service quality received is a response from consumers [10].

In providing services to students at the Raharja College, Raharja Internet Cafe still needs to know its influence on various lecture activities. In order for the quality of servants and facilities at Raharja Internet Cafe to students Raharja can be satisfying. Therefore, the menu of testimonials was used on the Raharja Internet Cafe website as a medium for delivering satisfaction information from buyers.

\section{Research Method}

\subsection{Literature Review}

The following is 8 (eight) scientific literature are used as references in this study [14] :

1. In the study entitled "OJRS + System Development (Online Study Plan Schedule Plus) as a Lecture Schedule Planning Media" conducted by Muhamad Yusup, Ary Budi Warsito \& Ninu Apriyani. The purpose of this research is to develop the OJRS system (Online Study Plan Schedule) which is one component contained in the SIS (Student Information System) which is also a facility for students who want to cancel the class schedule which is usually only accessible on SIS Box provided by the Raharja Campus. Developed into a system OJRS + (Online Study Plan Schedule Plus) based online who are inside the system SiS + (Students iLearning Services Plus). With the existence of this online -based OJRS + system, it is expected to facilitate students to access and cancel the scheduling of courses until students get the KSTF (Final Study Card) which can be accessed only by using a connection anytime and anywhere by students is [16].

2. In the study entitled "Facilities and Service Quality Influence on the Satisfaction of Users of Advent Manado Hospital Services" conducted by Steffi Mongkaren. This research is observational research that explains causation. This study has 2 variables namely independent variables / influencing variables and dependent variables / variables that are affected. This research is also conducted to find out and prove the effect of causation or relationships that influence and are influenced by the research conducted on these variables [17].

3. In the study entitled "The Effect of Facilities and Service Quality on Loyalty, Through Consumer Satisfaction as an Intervening Variable on the Star Clean Car Wash 
Semarang" conducted by Indra Lutfi Sofyan, Ari Pradhanawati \& Susanta Nugraha Day in 2013. The techniques used in collecting samples in this research is purposive sampling. with the following conditions: (1) Is a vehicle owner. (2) Within three months at least 3 times use the Star Clean Car Wash vehicle washing service. Using the interval scale using a Likert scale or Likert scale as a measurement technique. In collecting technical data used in the form of questionnaires and interviews, while the research instrument uses a questionnaire. In analyzing data, this study uses qualitative analysis and quantitative analysis. The analytical tool in this study uses validity test, reliability test, correlation analysis, regression analysis, coefficient of determination, significance test and path analysis [18].

4. In the study entitled "Perception About Service Quality, Value of Products and Facilities for Customer Satisfaction" conducted by Auli Lucky Yuriansyah in 2013. The purpose of this study was to determine the customer satisfaction of PO bus users. Muji Jaya Jepara and its influence on the perception of service quality, facilities and product value both simultaneously and partially. The results of this study are 1) There is an influence on perceived quality in service and customer satisfaction from PO bus users. Muji Jaya Jepara. In this context, the higher the PO bus. Muji Jaya Jepara in providing quality service, the higher customer satisfaction. 2) There is a perception of product values and perceptions of PO bus users. Muji Jaya Jepara towards customer satisfaction. In this context it means the application of product values to the PO bus. Muji Jaya offers a strategic role in supporting the implementation of marketing strategies. The higher the value of the product applied by the PO bus. Muji Jaya then will create customer satisfaction. 3) There is a perception of facilities and the influence of PO bus users. Muji Jaya Jepara towards customer satisfaction. In this context, the higher the application of facilities that are PO buses. Muji Jaya gives that the customer satisfaction obtained will also be higher. 4) Perception of service quality, product value, and facilities and their influence on the satisfaction of PO bus users. Muji Jaya Jepara simultaneously. This means the determination of service quality, product value, and facilities have an important or crucial role for PO bus users. Muji Jaya Jepara in order to support customer satisfaction, with the better quality of service, value of products, and facilities applied by PO buses. Muji Jaya [19].

5. Proceedings of the 2014 Yogyakarta National Science \& Technology (SNAST) Application Seminar on November 15, 2014 entitled "Analysis of Validity and Reliability with a Likert Scale of Si / Ti Development in Determining Decision Making in the Application of Strategic Planning in the Garment Industry". know the reliability of the development of IS / IT and how valid the development has been done in determining the decision making implementation of the planning strategy SI / IT Garment industry at PT. Elegant is seen in the view of employees at the management level [20].

6. In the research entitled "Customer Satisfaction Analysis With Fuzzy Service Quality Approach In Efforts to Improve Service Quality" conducted by Much. Djunaidi, Eko Setiawan and Tri Hariyanto (2006). The results obtained from the research on the condition of service by distributing questionnaires to the perceptions and services expected by customers provided by Kerjo Health Center, the gap value obtained between the expected perception of service is quite significant at $-3,361$ as the customer index. In this context, the services provided currently at Kerjo Health Center show that customer satisfaction has not been achieved [21].

7. In the study entitled "The Effect of Internet Learning and Utilization Facilities on Students' Achievements in the YOGYAKARTA Vocational School and Computer Engineering Expertise Program" conducted by Muhammad Fahmi Riza (2016), this study was conducted with the aim of (1) knowing student perceptions of the influence of facilities student learning, (2) knowing student perceptions of the influence of internet use, (3) knowing student perceptions of the influence of learning facilities and the use of the internet on student learning achievement. This study uses the Expost Facto Method, by collecting data using questionnaires and documentation. Respondents are XI grade students in the Network Computer Engineering expertise 
program at PIRI 1 YOGYAKARTA Vocational School. Evidence of instrument validation is done using calculations with the moment product correlation formula (Pearson) and expert judgment. The results obtained in this study are, learning facilities do not affect student learning achievement with Fcount <Ftable $(2.162$ $<3.26$ ), internet use has no effect on student learning achievement Fcount <Ftable $(0.457<3.26)$, Facilities learning and use of the internet did not significantly influence student achievement Fcount <Ftable $(1.055<3.26)$ [22].

8. In the research entitled "The Effect of System Quality, Information Quality, Service Quality of Rail Ticketing System (RTS) on User Satisfaction (Empirical Study at PT. KERETA API INDONESIA (PERSERO) DAOP JEMBER 9" conducted by Winda Septianita, Wahyu Agus and Winarno Alfi Arif (2015) this study aims to test the quality of the system, information, and services on the Rail Ticketing System (RTS) to the satisfaction of users of PT. Kereta Api (Persero) Daop 9 Jamber. Using questionnaire and interview methods in obtaining data and information for analysis [23].

\subsection{Method}

Taken from the Indonesian Large Dictionary $(\mathrm{KBBI})$, a questionnaire is a survey or research tool consisting of a series of written questions, aimed at getting a response through personal interviews or by post; list of questions from several groups of people selected [11]. The opinion expressed by Suharsimi Arikunto (2006: 224) depends on his point of view, this questionnaire or questionnaire can be distinguished according to its type [12-14]. Differentiated from:

Viewed according to the answer method:

1. Open questionnaire, giving the respondent an opportunity to answer using their own sentence.

2. The questionnaire was closed, the answers to this questionnaire were available so that respondents only had to choose. For example a column has been provided (Strongly Agree, Agree, Disagree, Strongly Disagree) then the respondent can choose one answer from the 5 columns.

Viewed according to the answers given:

1. Direct questionnaire, in the questionnaire directly the respondent gave an answer about himself.

2. Indirect questionnaire, in this indirect questionnaire the respondent will answer about other people. For example, a boss when asked to fill out a questionnaire assessment of his subordinates.

Seen according to its shape:

1. Multiple choice questionnaire, this questionnaire is the same as the closed questionnaire.

2. The oral questionnaire is a questionnaire similar to the open questionnaire.

3. The checklist is a list and the respondent just needs a check in the appropriate column.

4. Rating scale is a statement then followed by columns which are levels, for example starting from strongly agree to strongly disagree.

The questionnaire or questionnaire also has several advantages, namely:

1. Researchers do not have to be present.

2. Can be given in unison to many respondents.

3. Respondents can answer at their own pace and and when they are free.

4. Can be made without a name so the respondent can answer freely, honestly, and not shyly.

5. Can be made with standards so all respondents can give answers. 


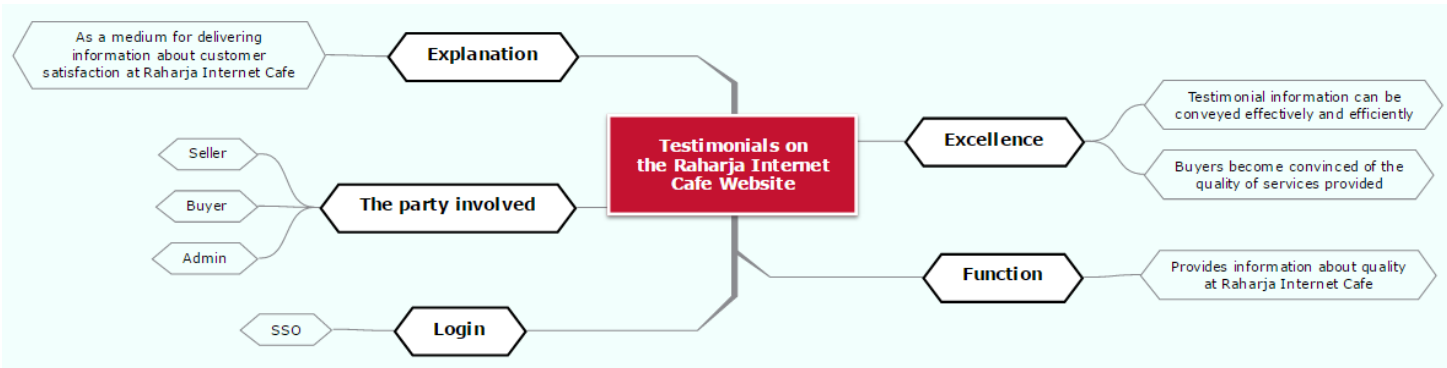

Figure 2. Mind map

Figure 2 above is a display of a mind map or mind mapping that explains the Testimonials menu on the Raharja Internet Cafe website, which consists of: (1) Explanation: as a medium for delivering information about customer satisfaction at Raharja Internet Cafe. (2) Parties involved: seller, buyer and admin. (3) Login: SSO ( Single Sign On ) using e-mail. (4) Excellence: testimonial information can be conveyed effectively and efficiently, and buyers become convinced of the quality of services provided. (5) Function: Provides information about quality at Raharja Internet Cafe [15].

\section{Findings}

To access the Raharja Internet Cafe website is not limited to the Personal Computer, various electronic media such as notebooks, laptops, tablets and mobile phones can be used, along with support from a good internet connection. In addition, the appearance of the neat and comfortable website Raharja Internet Cafe will have a positive impact on buyers who come to visit. The following are 5 (five) screenshots from the Raharja Internet Cafe website that are accessed using notebook media.

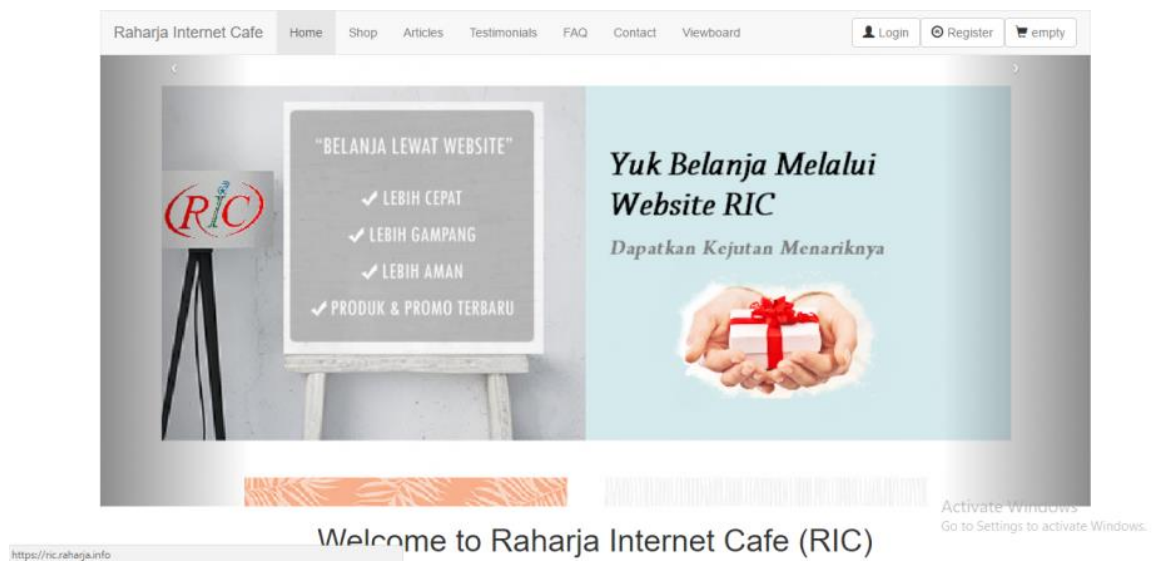

Figure 3. Raharja Internet Cafe website homepage

Seen in Figure 3, the interface of the main page or the homepage of the Raharja Internet Cafe website. At the top, there are 7 (seven) main menus, namely the home menu, shop, articles, testimonials, FAQ, contact and viewboard. The log in, register and check out menus are also located at the top right. In addition, there is also a banner that provides information about interesting news from the Raharja Internet Cafe website, 5 (five) top products that are often purchased by customers, and some photos from the situation that occurs at Raharja Cafe located in LV-002 Raharja College. 


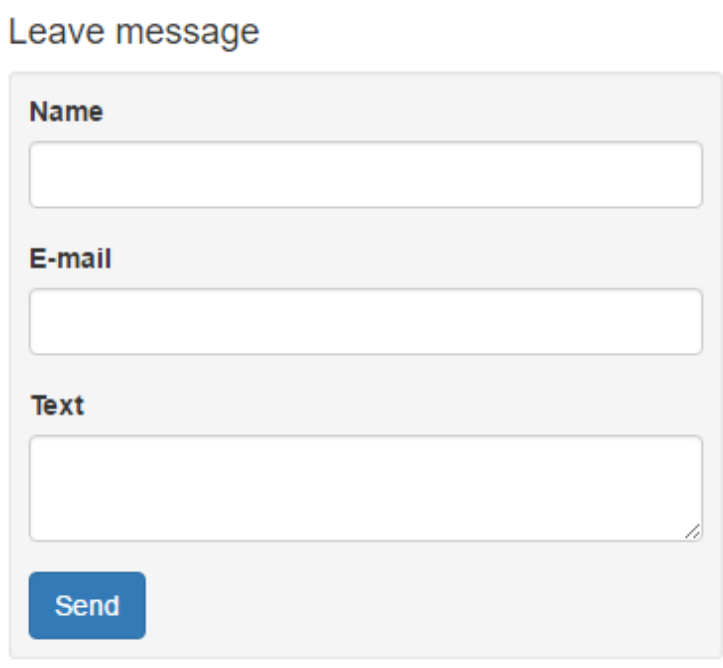

Figure 4. Input testimonials

Then as seen in Figure 4, it is a display of information input places to provide testimonials. There are 4 (four) parts, namely Name, E-mail, Text, and Send button . In the name column, the user must fill in his full name data, then fill in the e-mail address in the email column, and in the text column give a sentence containing satisfaction or experience after shopping through the Raharja Internet Cafe website, along with the Send button that must be clicked when has finished filling in all data.

\section{$\checkmark$ Message successfully added}

Figure 5. Notifications after sending testimonials

Then as seen in Figure 5, it is a display of notifications that appear when it has filled in the data and clicked on the Send button, which states that the message written has been successfully sent to the Raharja Internet Cafe.

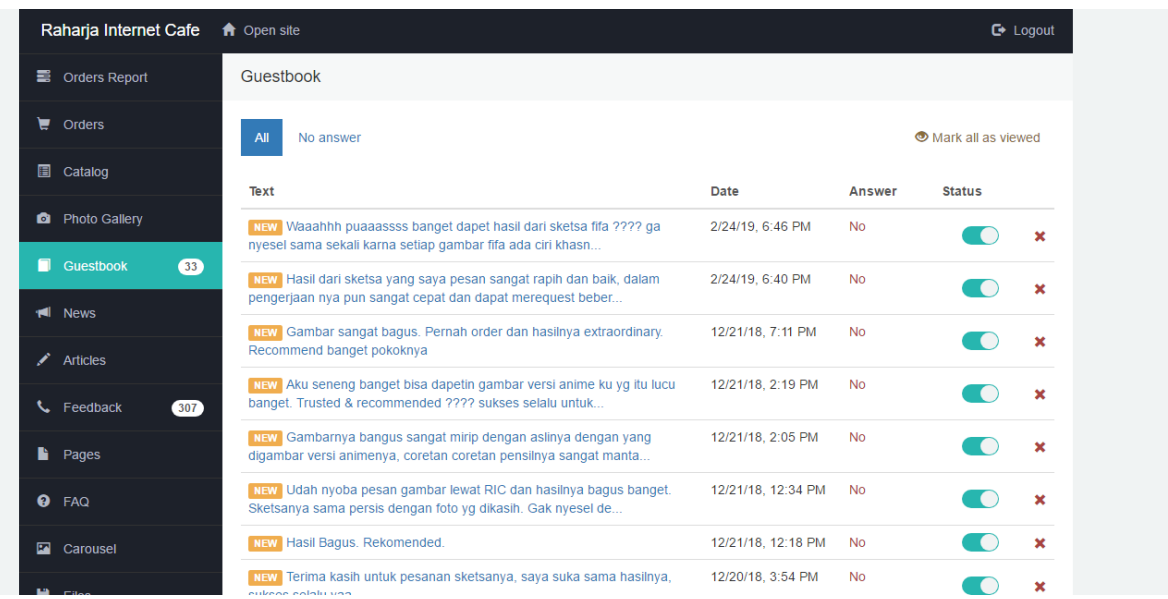

Figure 6. List of testimonials entered

Next is Figure 6, which is a display of the back office Raharja Internet Cafe, which can only be accessed by the Raharja Internet Cafe website admin, regarding a list of testimonials that were sent successfully. From this page, the admin can receive input and suggestions from buyers who have made transactions, so that in the future the service at Raharja Internet Cafe can be improved. 


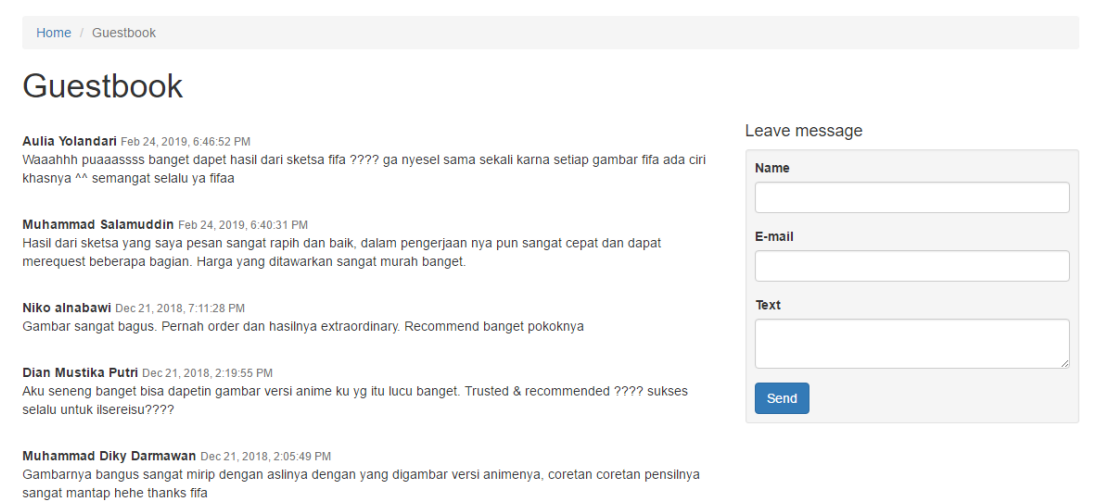

Figure 7. Testimonials

And the last one is Figure 7, displayed the interface from the testimonials menu which contains many testimonials from buyers at Raharja Internet Café. This testimonials page can be accessed by anyone, anytime and anywhere. So buyers who want to shop at Raharja Internet Café can receive information from othwe buyers regarding the service provided by Raharja Internet Café.

\section{Conclusion}

Raharja Internet Cafe is a place that provides Raharja's Personal needs for learning activities. Providing various facilities such as computers used by Pribadi Raharja for free. To measure the quality of services provided at Raharja Internet Cafe, it is necessary to obtain a lot of data from buyers for the services they experience, namely by providing testimonial data. Now Raharja Internet Cafe has an e-commerce website that can be accessed anytime and anywhere. By utilizing the Rharaja Internet Cafe website, buyers can provide their testimonials through the Testimonials menu, by filling in 3 (three) data, namely the name, e-mail address and testimonial text. Raharja Internet Cafe is very influential in teaching and learning activities at Raharja College. Thus, it can be concluded that Raharja Internet Cafe is useful in learning activities at Raharja College, supported by good facilities and good service.

\section{References}

[1] Rahardja, U., Aini, Q., Apriani, D., \& Khoirunisa, A. (2019). Optimalisasi Informasi Manajemen Laporan Assignment Pada Website Berbasis Content Management System. Technomedia Journal, 3(2), 213-223.

[2] Harahap, E. P., Rahardja, U., \& Salamuddin, M. (2019). Aplikasi Panduan dan Pembayaran Tiket Masuk Mendaki Gunung Menggunakan Metodologi Sistem Multimedia Luther-Sutopo. SATIN-Sains dan Teknologi Informasi, 4(2), 9-16.

[3] Aini, Q., Rahardja, U., Arribathi, A. H., \& Santoso, N. P. L. (2019). Penerapan Cloud Accounting dalam Menunjang Efektivitas Laporan Neraca pada Perguruan Tinggi. CESS (Journal of Computer Engineering, Science and System), 4(1), 60-64.

[4] Aini, Q., Dhaniarti, I., \& Khoirunisa, A. (2019). Effects of ILearning Media on Student Learning Motivation. Aptisi Transactions On Management, 3(1), 1-12.

[5] Aini, Q., Alwiyah, A., \& Putri, D. M. (2019). Effectiveness of Installment Payment Management Using Recurring Scheduling to Cashier Performance. Aptisi Transactions On Management, 3(1), 13-21.

[6] Rahardja, U., Sunarya, P. A., Aini, Q., \& Dewi, S. R. (2019). Solusi Payment Online Berbasis Cloud Accounting Pada Manajemen Perguruan Tinggi. InfoTekJar: Jurnal Nasional Informatika dan Teknologi Jaringan, 3(2). 
[7] Aini, Q., Alwiyah, A., \& Putri, D. M. (2019). Effectiveness of Installment Payment Management Using Recurring Scheduling to Cashier Performance. Aptisi Transactions On Management, 3(1), 13-21.

[8] Rahardja, U., Sunarya, P. A., Aini, Q., \& Dewi, S. R. (2019). Solusi Payment Online Berbasis Cloud Accounting Pada Manajemen Perguruan Tinggi. InfoTekJar: Jurnal Nasional Informatika dan Teknologi Jaringan, 3(2).

[9] Rahayu, N., Lestari, F. H. N., \& Aprilyani, U. T. (2017). Clothing Sales Information System Web-Based:"Bluelight Distro". VOLT: Jurnal IImiah Pendidikan Teknik Elektro, 2(1), 55-62.

[10] Febriyanto, E., Rais, N. S. R., \& Syafaah, F. (2019). Penerapan Aplikasi Tawk To IduHelp! Sebagai Sarana Pelayanan Informasi di Perguruan Tinggi. Technomedia Journal, 3(2), 246-259.

[11] $\mathrm{KBBI}, 2017$, Kamus besar bahasa Indonesia [Online], (diakses pada tanggal 03 Desember 2017) tersedia di https://kbbi.web.id/.

[12] Sugiyono (2010). Metode Penelitian Kuantitatif Kualitatif \& RND, Bandung: Alfabeta.

[13] Sugiyono (2014). Metode Penelitian Pendidikan Pendekatan Kuantitatif, Kualitatif Dan R\&D, Bandung: Alfabeta.

[14] Umar, H. (2000). Metodologi Penelitian, Jakarta: Gramedia Pustaka Umum.

[15] Handayani, I., Kusumahati, H., \& Badriah, A. N. (2017). Pemanfaatan Google Spreadsheet Sebagai Media Pembuatan Dashboard pada Official Site iFacility di Perguruan Tinggi. Sisfotenika, 7(2), 177-186.

[16] Yusup, M., Warsito, A. B., \& Apriyani, N. (2016). Pengembangan Sistem OJRS+ (Online Jadwal Rencana Studi Plus) Sebagai Media Perencanaan Jadwal Kuliah. CCIT Journal. Perguruan Tinggi Raharja.

[17] Mongkaren, S. (2013). Fasilitas dan Kualitas Pelayanan Pengaruhnya Terhadap Kepuasan Penguna Jasa Rumah Sakit Advent Manado. JURNAL RISET EKONOMI, MANAJEMEN, BISNIS DAN AKUNTANSI, 1(4).

[18] Sofyan, I. L., Pradhanawati, A., \& Nugraha, H. S. (2013). Pengaruh fasilitas dan kualitas pelayanan terhadap loyalitas, melalui kepuasan konsumen sebagai variabel intervening pada star clean car wash Semarang. Jurnal Ilmu Administrasi Bisnis.

[19] Yuriansyah, A. L. (2013). Persepsi Tentang Kualitas Pelayanan, Nilai Produk Dan Fasilitas Terhadap Kepuasan Pelanggan. Management Analysis Journal, 2(1).

[20] Janti, S. (2014). Analisis Validitas Dan Reliabilitas Dengan Skala Likert Terhadap Pengembangan Si/Ti Dalam Penentuan Pengambilan Keputusan Penerapan Strategic Planning Pada Industri Garmen. In Prosiding Seminar Nasional Aplikasi Sains \& Teknologi (SNAST) (pp. 155-160).

[21] Djunaidi, M., Setiawan, E., \& Hariyanto, T. (2006). Analisis kepuasan pelanggan dengan pendekatan fuzzy service quality dalam upaya peningkatan kualitas pelayanan. Jurnal IImiah Teknik Industri, 4(3), 139-146.

[22] Muhammad, F. R. (2016). Pengaruh Fasilitas Belajar Dan Pemanfaatan Internet Terhadap Prestasi Siswa Program Keahlian Teknik Komputer Jaringan Smk Piri 1 Yogyakarta (Doctoral dissertation, UNY).

[23] Septianita, W., Winarno, W. A., \& Arif, A. (2014). Pengaruh Kualitas Sistem, Kualitas Informasi, Kualitas Pelayanan Rail Ticketing System (RTS) terhadap Kepuasan Pengguna (Studi Empiris pada PT. Kereta Api Indonesia (PERSERO) DAOP 9 Jember). E-Journal Ekonomi Bisnis dan Akuntansi, 1(1), 53-56 